\title{
The Development Standard Agreement Influences on National and International Business Practices
}

\author{
Cindawati \\ Faculty of Law, Palembang University \\ Jln. Dharmapala No. 1A Bukit Besar, Palembang, 30139, South Sumatera, Indonesia \\ Tel./Fax:+62-711-440650Email: cindawatis@yahoo.com \\ Submitted: Sep 9, 2016; Reviewed: Nov 13, 2016; Accepted: Nov 21, 2016
}

\begin{abstract}
The rapidly growing business traffic either nationally or internationally forces the business practices to establish a standard agreement to secure the products and to protect the buyer from any risks. The standard agreement successfully meets the demand of international trade which urgently need the high speed and the accuracy. The objective of this research is to find out how does the development of agreement affect to the commerce practices and what are the requirements of standard agreement in accordance with the right and obligation. A qualitative method is applied in searching data of business practices. This study uses a normative research which guides the rule of law or determines some business standards and norms. The finding of this study show that the development of agreement strongly affects to the commerce practices, and standar agreement is urgently needed by business practices as a guideline to perform business traffic as smooth as buyer and seller expect, then both seller and buyer should know the three alternative way used as the procedures of standard agreement, namely; contract signing, notification document agreement, and notification by bulletin board. At last, a standard agreement could be accepted as legal agreement corresponding to willingness and trustworthy.
\end{abstract}

Keywords: Contract; International Law; International Trade; Standard Agreement

DOI: 10.20956/halrev.v2i3.698

\section{INTRODUCTION}

The Indonesian Civil Code is also known as Material Civil Code, which is divided into two kinds, namely; Material Civil Code and Formal Civil Code. Material civil code is the law which defines and regulates both rights and obligations. While, formal civil code is the law which decides and regulates the procedures of performing the rights and obligations itself. In addition, Indonesia also concerns about legal assetc code (Vermogent recht) which regards to the rights and obligations reffered to the party who involved in an agreement. In this case, legal asset code is divided into kinds as well, namely; (a) zakenrehct; and (b) verbintenissenrecht. These two kinds of law set all the commerce law. The commerce law lies on engagement regulation in performing the company cases. Commonly, the engagement comes from the agreement or it could be based on the available laws in which there are many kinds of 
agreement, such as; transporting, insurance, buying and selling companies, broker commisioner, money order and cheque.

The company activities urgently need the agreement because it is a legal act which is done by between two or more parties to promise each other, to do an agreement, or to give necessary. This is also extremely stated in Article1320 KUH Civil Code; the valid agreement should have some requirements, namely; (a) agreement; (b) commitment; and (c) legality. Moreover, Article 1320 act (1) also states that the agreement also called as license which means the two parties which involve in performing the engagement must totally agree each other on the matter subject of that agreement. In other words, the two parties must have some goals. For instance; a seller wants to have some money through selling the product, and a buyer really wants to have the product needed from the buyer.

The above example shows that buying and selling activity has a tough principle which is known as consensualitas principle. Basically, konsensualitas principle is the engagement which has been achieved as soon as the agreement is done at the very first time. In this case, the agreement is valid and two parties do not longer need any formal licenses or it is called as Consensus. The Consensus has two essential requirements; (a) subjective requirement in which it could be first and second requirement and (b) objective requirement. In which it could be third and fourth requirement. For example; if the subjective requirement is not fulfilled, the agreement may be cancelled whereas if the objective requirement is not fulfilled, everything is cancelled will be back to the laws.
From the background above this research focuses on the national and international trade that extremely must have some contracts. The contracts or agreements play an essential role in performing bussiness. Thus, the agreement will be the law sources to carry out the rights and obligation. Therefore, in carrying out the research, it is necessary to formulate the problems of the research; (1) does the development of agreement affect to the commerce practices? (2) what is standard agreement? (3) How is the procedure of standard agreement? (4) What are the requirements of standard agreement in accordance with the right and obligation?

\section{METHOD}

This study was conducted by using a normative juristic approach which guides the rule of law or determines some standard and norms against a phenomenon. By analyzing secondary data or documents, this study interprets the records. Furthermore, Data were selected in accordance to the three law sources, namely; (a) primary law which includes legislation, (b) secondary laws which include relevant documents, national and international journals, theories and (c) tertiary law which includes dictionary, encyclopedia, and black laws.

Data collecting will be taken from data secondary and interviewing the various subjects who will be as the source of data. In order to be more in-depth research, this study will be conducted by using qualitative approach since it will present the description based on case study rather than statistical data. 


\section{ANALYSIS AND DISCUSSION}

The Development of Agreement Affects the Commerce Practices

In trade practices, the agreement plays an essential role since there is a tough principle in performing an agreement. This principle is known as consensual. Consensual means the engagement have been achieved as soon as the agreement is done at the very first time. The agreement statement shoud be declared by two parties which involved in the engagement. This statement would be used as benchmarks for the agreement, and this statement could be a provement to the judge. Thus, the two parties feel safe when they both declare the agreement statement.

Commonly, the agrrement will be achieved if there is an offering product by one party then another party accepts and deals with it. From this step, both two parties automatically bond themselves each other. In addition, both two parties do not know their own rights and obligations but also they should respect each other since the sense of agreement is a set of promise which can be forced and also there is recognition of consensus principal, recogniton of freedom.

There are many freedom limitation of the contract (agreement), namely; (a) the freedom can not be opposite to the law, morality and politeness; (b) contract status which means both national and international contracts are limited and protected by particular country; ${ }^{1}$ (c) restrict bond which binds the two parties ${ }^{2}$. Agreement or contract.

Sudargo Gautama. (1976). Kontrak Dagang Internasional. Bandung: Alumni, p. 65.

2 Michelle Sanson. (2002). Essential International Trade Law. Sidney: Cavendish, p. 7.
The agreement or contract is very useful for national and international trade. ${ }^{3}$ The contract ought to meet the international demands which urgently need speed and accuracy. There are many affecting factors for the international commerce contract, they are; (a) the effeciency of cost, time, and energy, (b) practical, there is an available form (c) quick settelement, buyers only need to sign the form (d) homogenity. Unfortunately, this kind of contract or agreement seems to give a great benefit to the seller and it does not take side to the buyer since the buyer can not negotiate all the requirements available. The buyer only signs the form and if the buyer tries to do a negotiation, the contract will be cancelled.

In the developing country, bussinessmen already implemented this kind of agreement as economic principal in order to face the social demands. Yet, there is no a big trouble if this kind of agreement is used by businessmen. They will take a great benefit from this agreement since they have same mission "Implementing the fair competition system to serve the consumers". In addition, if they have a mission "Performing a business to satisfy either seller and buyer", absolutely it will make a mutual relationship between a seller and a buyer.

In relation to the statement above, between a seller and a buyer have to know the term "standard contract" or "standard agreement". It is used to be a benchmark or guideline for every consumers who want to have a legal law with the sellers or busi-

\footnotetext{
Munir Fuady. (2003). Hukum Kontrak dari Sudut Pandang Hukum Bisnis. Bandung: PT Citra Aditya Bakti, p. 77
} 
nessmen. ${ }^{4}$ There are many factors affecting the standard contract or standard agreement, namely; (a) model (b) formula and (c) size. The implementation of standard contract or standard agreement hardly face the terrible trouble among busnissmen since they have same mission in performing the business practices.

\section{Standard Contract or Standard Agree- ment}

Some experts state that the definition of a standard contract. Firstly, according to Hondoius, ${ }^{5}$ a standard contract is a written agreement which sets without any discussion, usually it is set into some specific agreements. Secondly, according to Badrulzaman, ${ }^{6}$ the standard contract is an agreement which standardized and set in the form. From the theories above, the agreement usually contains the statements and it is printed out in some copies and used to all commerce practices. In short, it is set seller yet made by seller and buyer. There are five characteristics of a standard contract, namely;

1. Written

2. Standardized

3. Set by businessmen

4. Dispute resolution is done through discussion

5. The standard agreement only gives a great benefit to the businessmen

$4 \quad$ Amir M.S. (2002). Kontrak Dagang Ekspor. Jakarta: PPM, p. 17.

Hondius E.H. (1978). Syarat-syarat Baku dalam Hukum Kontrak, Artikel dalam Kompedium Hukum Belanda. Yayasan Kerjasama Ilmu Hukum Indonesia Belanda di is-Gravenhage, p. 39

6 Mariam Darus Badrulzaman. (1994). Aneka Hukum Bisnis. Bandung: Alumni, p. 7
Furthermore, a standard clause is any rules, regulations, and requirements which are prepared and determined by businessmen which is written in the documents and must be obliged by seller. According to Articel 18(1) Law No. 8 of 1999 concerning Consumer Protection; businessmen are a group of people who offer product and service for trading, and they are not permitted to make a standard clause if the following factors exist:

1. Declaring the responsibility business change.

2. Declaring that businessmen refuse the products delivered to be bought by consumers.

3. Declaring that businessmen have rights to handover paid money.

4. Declaring that authorization from consumers to the sellers either directly or indirectly relating to a unilateral perform.

5. Setting the proof related to the loss of products or services.

6. Allowing the business practices to reduce the quality and quantity of products and services.

7. Giving additional regulations.

8. Declaring that consumers are free from enmburance, lien, and security rights againts deffered payments.

Moreover, there is a responsibility and exonaration in a standard contract. It is such realization from the obligation of one party. In order to realize this obligation, the long process in needed in which to fulfill either complete or incomplete rights. The complete right is done when the obligation is implemented properly and both parties have their own rights as well. Whereas, the incomplete 
right is done when obligation is not implemented properly and both partis do not have their rights. The implementation of responsiblity only give a great advantages to the seller. Since, there are some requirements needed in responsbility making process in which the consumer will have more responsbility than seller againts the product bought. The example of illustration of exonaration case is as stated as the following:

"A consumer who wants to rent a product will be fully responsible for any damages, loss, and regulation changing. In other words, if the product is lose, damaged, or gone, the consumer absolutely will be responsible for any reimbursements and repairment. The consumer is asked to wear the product rented carefully in accordance with all the regulations required because the consumer are fully responsible for the product rented. While, the businessman who offers the product is free from any responsibility. Then, the worse thing occurs when the consumer use the product carefully but it remains broken or damaged. While, the businessmen are free from any responsibility".

The illustration above can not be avoided since according to article 1338 (1) stated the principle of contract freedom in which both seller and buyer have a freedom to create a legal agreement as long as they do not outrage public order and morality. The laws only forbid the responsbility arising from coercion, mistake, fraud and incompetence. (Article 1321-1331). To keep the law, the Indonesian government create a judicial board under legislation in order to create the justice. So, if the the obligation is not carried out properly, both seller and buyer have possibility to ask the solution from the judicial board to have the justice.

The implementation of exonaration is only used to prove that the businessmen in the right side. That is why, exonaration only can be implemented in "Good Faith Principles". According to The International Institute for The Unification of Private Law in Article $1.7^{7}$, there are two principles of good faith, namely : (a) dealing with the international trade and (b) unlimit responsibility. Moreover, these two principles are restated to have a comprehensive understanding, or it is known as restatement. The restatement pays a full attention to the principle above, and it creates three principles of good faith, namely; (a) proper intention and honesty as contract-based (b) proper intention and honesty againts UPPICS (UNIDROIT Principles of International Commercial Contract and (c) forcement.

From these principles, it can be concluded that the main purpose is to implement the good faith and fair dealing in each of International commercial contract. In addition, it will creat the harmonization of law. Shortly, UNIDROIT The International Institute for The Unification of Private Law can be used as reference ${ }^{8}$. Therefore, the court can prevent the implementation of exoneration since it does not give the benefits to seller and buyer. Businessmen and consumer should understand their own responsibilty. Businessmen give a good service and offer, while buyer who acts as king should consider their attitude in order to avoid loss.

\footnotetext{
Taryana Soenandar. (2004). Prinsip-prinsip UNIDROIT sebagai Sumber Hukum Kontrak dan Penyelesaian Sengketa Bisnis Internasional. Jakarta: Penerbit Sinar Grafika, p. 17

Ibid.
} 
There are three possibilities of exoneration used in agreement requirements; First, the exoneration againts law enforcement. In this case, the agreement belongs to the consumers, while a seller is free from any responsibility. For instance; if the rented product is burned, the consumers have a full responsibility to paid the cost left; Second, exoneration againts a seller which harm the second party. In this case, the mistake belongs to the seller but the seller is not responsible for that product. It occurs because of some factors, such as; stale, unwell. For instance; the product is carried by a particular transportation in a long trip, but any loss does not belong to the seller or courier; and third, exoneration againts a seller which harm the third party. In this case, the mistake belongs to the seller, but the loss belongs to the third party.

\section{The Procedure of Standard Agreement Contract signing}

All the agreements are written in details then it is signed by both a seller and a buyer. A consumer is asked to read the contract in advance, the next step is sigining the contract after the consumer agrees with all contents of agreement.

\section{Notification by document agreement}

Agreement regulation standard is given to the other party to be understood well. If the parties agree with what they have read, they may to sign it. Usually, the document is printed out and not signed by consumers, the kinds of documents are; shipment letter, inquiry letter, and invoice. So, the consumer has to agree with all agremeent written in the letter

\section{Notification by bulletin board}

The requirement can be informed through bulletin board in the business place. The court is established in all the business place. It should have a big bulletin board, so it is readible by anyone who wants to have business desire. The bulletin board can be found in some business place, such as; workshops, stations, and supermarkets

\section{The Requirements of Standard Agree- ment in Accordance with the Rights and Obligations}

The growing of society needs' makes the characteristics of legal agreement must meet the demand of society. There are two basic principles; economic principles and law implementation. These two principles will be standing on seller's side since the consumers do not involve in agreement making, they only need to accept all the agreements.

Badrulzaman, ${ }^{9}$ states that standard contract or standard agreement could be accepted as legal agreement corresponding to willingness and trustworthy (fictie van wil en vertrouwen) to evoke the parties' trustworthy in performing the business practices. The development of international business or trade based on common interest and profit is an important element in the effort to foster good international relations. This is based on the view that the establishment of uniform regulations, which will regulate contracts of the international trade of goods and the taking into account social, economic and legal system differences, will contribute towards the eradication of various obstacles and hindrances of legal contracts in international

Badrulzaman. (1994). Op.Cit., p. 53. 
business or trade. ${ }^{10}$

Legal Contract in international business continues to grow dynamically follow and respond to the challenges and demands of the times are changing and growing rapidly driven by the progress of advanced technology and electronic communications, has focused on the agreement or contract with standards or contract standards, referring to the results of bilateral agreements, regional cooperation and international conventions and international law.

Legal Contract in international business in the practice of international trade tasted qualified transnational business, which is characterized by an attitude of reasonableness that is based on mutual respect clauses agreed contract (fairness). Fairness in the justice of each party means that international trade practices as outlined in the International Business Contract Law adhering and respecting the principle of balance.

Considered very relevant principle of Balance in International Business Contracts, as businesses realize true that in today's business competitive nuanced and quite tight. In these circumstances the "good name" of a company as international business people must be kept absolutely. Attitude maintain and guarantee the identity of legal subjects as business people do, at least, with a business policy that prioritizes the quality of the products (quality reliable) and perfect service, covering You keep appointments, transportation services and others, so that importers

10 In the existing international trade, the implementation is regulated by a business contract between two countries (bilateral agreement) or by the default standard established by a convention agreed upon by different countries, such as business agreements regulated by the World Trade Organization (WTO). were satisfied with the achievement of service exporters so that in general any business contracts implemented as agreed.

Business contract law that a legal basis which facilitate transnational business can certainly apply the principle of balance, to ensure the rights and interests of civil parties who are bound in International Business Contracts. In fact, it can be said, that the Contract Law Business and Principles complement Balance is always in togetherness. Each party to a contract of international business and want to always keep alert, so it is not harmed in business contracts with other parties, at the same time each party to the contract business does not want to disappoint others. It is due to that in an increasingly competitive business nuances absolute must produce excellent product and service business were satisfactory, so as not excluded by competitors. Therefore, "The principle of balance" is always applied in the Law of International Business Contracts.

In international trade, there are two laws of ICC (International Chamber of Commerce), namely; UCP (The Uniform Customs and Practices for Documentary Credits), and Incoterms 2000 (The International Commerical Terms). Incoterms is established to defines the standard contract universally which covers the terms used in International trade. Incoterms used as guideline to sales contract to overseas and upcoming contract needed in performing International business ${ }^{11}$.

Hondius $^{12}$ in his Dissertation elaborated that the standard contract is used as a tough bond based on the custom of society and trade traffic. In developing countries, a 11 Amir M.S. (2002). Op.Cit., p. 17.

12 Hondius E.H., (1978). Op.Cit., p. 55. 
standard contract plays an important role in trade traffic particularly international trade in order to increase economy growth. Trade association welcomes this policy since it is going to protect and to facilitate the business traffic. Government needs to let the businessmen know the kinds of sale contract in details. Incoterm 2000 can be used as guidline to understand sales contract universally. All business practices are secured by laws with requirement trade Free on Board (FOB).

For example, the export -import case of PT Pusri which is based on FOB in 2008. PT. Pusri is an exportir of urea in foreign countries, such as; Philipina, Australia, China, Vietnam and Korea. PT Pusri has establihed the standard contract and used it as guidelines to limit all the complicated regulations. So, PT Pusri knows how to decide the place where the sellers sell the products to the buyers physically and juridically. Eventhough, each point of perfoming business has the high risks, such as; loss, damage, transportation affair, and costs, in which all the risk belongs to the buyers.

PT Pusri has the responsibility from loading port to transaction with the buyers. There are two factors underlying PT Pusri determined to used FOB, namely; (a) the number of ships, somehow it is going to be difficult to find the availabe ship and the decreasing of ships, (b) due to PT Pusri responsible for exporting, PT Pusri does not want to take high even higher risks, such as; loss, damage, transportation affair, and costs. In addition, the price of urea is still cheap since the buyers have to pay all payements and risks. The price of FOB includes product and shipping costs.

\section{CONCLUSION}

The development of agreement affects the commerce practices. An Exonaration may be used in agreement good faith-based since principally it only gives a great benefit to the buyers while sellers will take all the risks. A Standard contract or Standard agreement is used to be benchmark or guideline for each consumer who wants to have a legal law with the seller or businessmen. There are many factors affecting the standard contract or standard agreement, namely; (a) model; (b) formula; and (c) size. In performing the standard agreement, both a seller and a buyer should know the three alternative ways used as the procedures of a standard agreement, namely; contarct signing, notification document agreement, and notification by bulletin board. A standard agreement could be accepted as a legal agreement corresponding to willingness and trustworthy. Hence, the sellers and buyers understand their own rights and obligations prior to perfoming the business traffic.

\section{BIBLIOGRAPHY}

Amir M.S. (2002). Kontrak Dagang Ekspor. Jakarta: PPM.

Hondius E.H. (1978). Syarat-syarat Baku dalam Hukum Kontrak, Artikel dalam Kompedium Hukum Belanda. Yayasan Kerjasama Ilmu Hukum Indonesia Belanda di is-Gravenhage.

Mariam Darus Badrulzaman. (1994). Aneka Hukum Bisnis. Bandung: Alumni.

Michelle Sanson. (2002). Essential International Trade Law. Sidney: Cavendish.

Munir Fuady. (2003). Hukum Kontrak dari Sudut Pandang Hukum Bisnis. 
Bandung: PT Citra Aditya Bakti.

Sudargo Gautama. (1976). Kontrak Dagang

Internasional. $1^{\text {st }}$ edition. Bandung: Alumni.

Taryana Soenandar. (2004). Prinsip-prinsip UNIDROIT sebagai Sumber Hukum Kontrak dan Penyelesaian Sengketa Bisnis Internasional. Jakarta: Penerbit Sinar Grafika.
UNCITRAL (United Nations Commission on Trade Law) Arbitration Rules.

UNIDROIT (The United Nations Commission on International Trade Law).

Uniform Customs Practice for Documentary Credit (UCP 500).

Uniform Customs Practice for Documentary Credit (UCP 600) Revision 2007, ICC Publication 600. 